\title{
Multicentric Ipsilateral Invasive Breast Carcinomas Might have Higher 21-Gene Recurrence Score Compared with Multifocal Ipsilateral Invasive Breast Carcinomas
}

\author{
Kadri Altundag \\ MKA Breast Cancer Clinic, Tepe Prime, Cankaya, Ankara, Turkey
}

Dear Editor,

I want to congratulate Grabenstetter and collegaues for their article in which they investigated the concordance of the 21-gene recurrence score (RS) in multifocal (MF)/multicentric (MC) ipsilateral invasive breast carcinomas (BCs) with similar histology. ${ }^{1}$ They reported that morphologically similar multifocal ipsilateral BCs have concordant RS in $87 \%(46 / 53)$ of cases. However, the authors did not describe the number of cases with MC or MF tumors that may affect outcome. A retrospective, institutional database was used to compare characteristics of MF and MC BCs with unifocal cancers. They reported that $\mathrm{MF}$ and $\mathrm{MC}$ tumors seem to be biologically different diseases. MC BCs are clinicopathologically more aggressive than MF $\mathrm{BCs}$, are more frequently associated with younger age and larger tumor size, and also are an independent predictor of node positivity. ${ }^{2}$ Therefore, MC BCs might have higher RS compared with MF BCs. This issue merits further investigation.

\section{REFERENCES}

1. Grabenstetter A, Brogi E, Chou JF, Morrow M, Dickler M, Norton L, Wen HY. Multifocal/Multicentric Ipsilateral Invasive Breast CARCINOMAS with Similar Histology: Is Multigene Testing of All Individual Foci Necessary? Ann Surg Oncol. 2018. https://doi. org/10.1245/s10434-018-6866-y.

2. Kanumuri P, Hayse B, Killelea BK, Chagpar AB, Horowitz NR, Lannin DR. Characteristics of Multifocal and Multicentric Breast Cancers. Ann Surg Oncol. 2015;22(8):2475-82.
(C) Society of Surgical Oncology 2018

First Received: 12 October 2018;

Published Online: 19 November 2018

K. Altundag

e-mail: altundag66@yahoo.com 